\title{
Correction to: Targeting Sphingosine-1-Phosphate Signaling in Immune-Mediated Diseases: Beyond Multiple Sclerosis
}

\author{
Tamara Pérez-Jeldres ${ }^{1,2} \cdot$ Manuel Alvarez-Lobos $^{1,2} \cdot$ Jesús Rivera-Nieves $^{3,4}$ (D)
}

Published online: 30 July 2021

(c) The Author(s) 2021

\section{Correction to: Drugs (2021) 81:985-1002 https://doi.org/10.1007/s40265-021-01528-8}

Please note that the drug cenerimod has been misspelled twice in this article as cerenimod.

Section 3.5.1 Cenerimod, second paragraph on page 994. The fourth sentence, which currently reads

"At week 11, 30\% in the vehicle group died, whereas all cerenimod-treated mice survived."

Should read:

"At week 11,30\% in the vehicle group died, whereas all cenerimod-treated mice survived."

Section 4.2 Cardiovascular Events, first paragraph on page 944 . The eighth sentence, which currently reads

"Conversely, up-titration is not required for compounds with long half-lives (fingolimod, cerenimod) due to the less pronounced first-dose-related negative chronotropic effects, presumably due to "built-in up-titration" $[4,110]$."
The original article can be found online at https://doi.org/10.1007/ s40265-021-01528-8.

Jesús Rivera-Nieves

jriveranieves@ucsd.edu

Pontificia Universidad Católica de Chile, Santiago, Chile

2 Hospital San Borja-Arriarán, Santiago, Chile

3 San Diego VA Medical Center (SDVAMC), San Diego, CA, USA

4 Division of Gastroenterology, Department of Medicine, University of California San Diego (UCSD), 9500 Gilman Drive Bldg. BRF-II Rm. 4A32, San Diego, CA 92093-0063, USA
Should read:

"Conversely, up-titration is not required for compounds with long half-lives (fingolimod, cenerimod) due to the less pronounced first-dose-related negative chronotropic effects, presumably due to "built-in up-titration" $[4,110]$."

Open Access This article is licensed under a Creative Commons Attribution-NonCommercial 4.0 International License, which permits any non-commercial use, sharing, adaptation, distribution and reproduction in any medium or format, as long as you give appropriate credit to the original author(s) and the source, provide a link to the Creative Commons licence, and indicate if changes were made. The images or other third party material in this article are included in the article's Creative Commons licence, unless indicated otherwise in a credit line to the material. If material is not included in the article's Creative Commons licence and your intended use is not permitted by statutory regulation or exceeds the permitted use, you will need to obtain permission directly from the copyright holder. To view a copy of this licence, visit http://creativecommons.org/licenses/by-nc/4.0/. 